\title{
ON MANUFACTURE OF HEAT-RESISTING STEEL CONTAINING HIGH CONCENTRATION OF NITROGEN AND ITS HIGH TEMPERATURE PROPERTIES
}

\author{
Ryohei TANAKA*, Takayuki SHINODA* and Yoichiro TOBE** \\ * Tokyo Institute of Technology, Tokyo, Japan \\ ** Formerly Tokyo Institute of Technology, Tokyo, Japan, \\ and now at Technical Research and Development Institute, \\ Japan Defense Agency, Tokyo, Japan
}

\begin{abstract}
To utilize nitrogen as an alloying element in heat-resisting steels, an experimental study was made on the fundamental phenomena occurring in melting and casting of various high-chromium steels under high-pressure nitrogen atmosphere. By this technique, sound ingots containing high concentration of nitrogen could practically be obtained, and the new high strength heat-resisting steel could be developed, some of which have the creep-rupture strength at $700^{\circ} \mathrm{C}-10^{3} \mathrm{hr}$ tar exceed $20 \mathrm{~kg} / \mathrm{mm}^{2}$ with an excellent high-temperature ductility.
\end{abstract}

\section{Introduction}

It has been known for many years that nitrogen has an excellent potential as an alloying element in austenitic stainless steels and heat-resisting steels $[1 \sim 4]$. However, in the ordinary method of melting and casting, it is seldom that the stably alloyable nitrogen content surpasses $0.2 \%$ in the austenitic steels, except for such high-manganese steel as a 21-4N valve steel. Even if the nitrogen above this value were added in the melt, a sound ingot could not be obtained, because of blowholes on solidification. On the other hand, it is stated that the nitrogen solubility in molten and solidified iron is nearly proportional to the square root of the partial pressure of the nitrogen gas in the atmosphere [5]. Subsequently, it is expected that if the pressure of nitrogen gas in the melting atmosphere is enhanced, the stably alloyable nitrogen content will be increased.

From this view point, one of the authors have projected a research on melting in nitrogen under high pressure. By developing melting and casting method in nitrogen atmosphere under high pressure up to $10 \mathrm{~atm}$ [6] [7], the basic conditions for the stable and sure melting of some stainless and heat-resisting steel have been established. Some of the steels produced by this method contained such high concentrations of nitrogen that they previously could not be expected to be melted properly under the ordinary method. There was found only a few examples of the melting in nitrogen atmosphere under high pressure $[3,8,9]$, so that the potential of this method has not been properly recognized. The present paper gives a summary of the research on melting in high-pressure nitrogen performed previously by the authors including a part of the results of the study on heat-resisting properties of steel products containing nitrogen up to about $0.6 \%$ or $0.7 \%$.

\section{High-Pressure Melting Furnace and Melting Procedure}

The high-pressure melting furnace used in this experiment is a $15 \mathrm{kVA}$ high-frequency induction furnace that has a structure similar to that of the common insideheating type vacuum-melting furnace, but both vacuum tank body and many vacuum sealing parts are designed and manufactured so as to stand an inner pressure of 15 atm max. Figure 1 shows an apparence of this tank which is of a horizontal cylinder type with a diameter of about $800 \mathrm{~mm}$ and a length of about $800 \mathrm{~mm}$ and additionally equipped with vacuum pump in order to replace the air in the tank with nitrogen. The melting quantity per charge is $5 \mathrm{~kg}$ and a crucible of fused magnesia with an inside diameter of $85 \mathrm{~mm}$ is used. The depth of the $5 \mathrm{~kg}$ molten steel is about $100 \mathrm{~mm}$.

Base materials, consisting of electrolytic iron, chromium and nickel, were previously charged into the crucible, melted down in a vacuum and heated to about $1550^{\circ} \mathrm{C}$. Then a high-purity nitrogen was introduced to make $1 \mathrm{~atm}$. Then manganese, silicon, molybdenum, tungsten and boron were added and again nitrogen yas was introduced. When the gas reached the required pressure, the metal was kept for the required time and then cast into the mold in the atmosphere under the same pressure. The mold, made of copper was of the square or round type with the dimension of about $180 \mathrm{~mm}$ in 


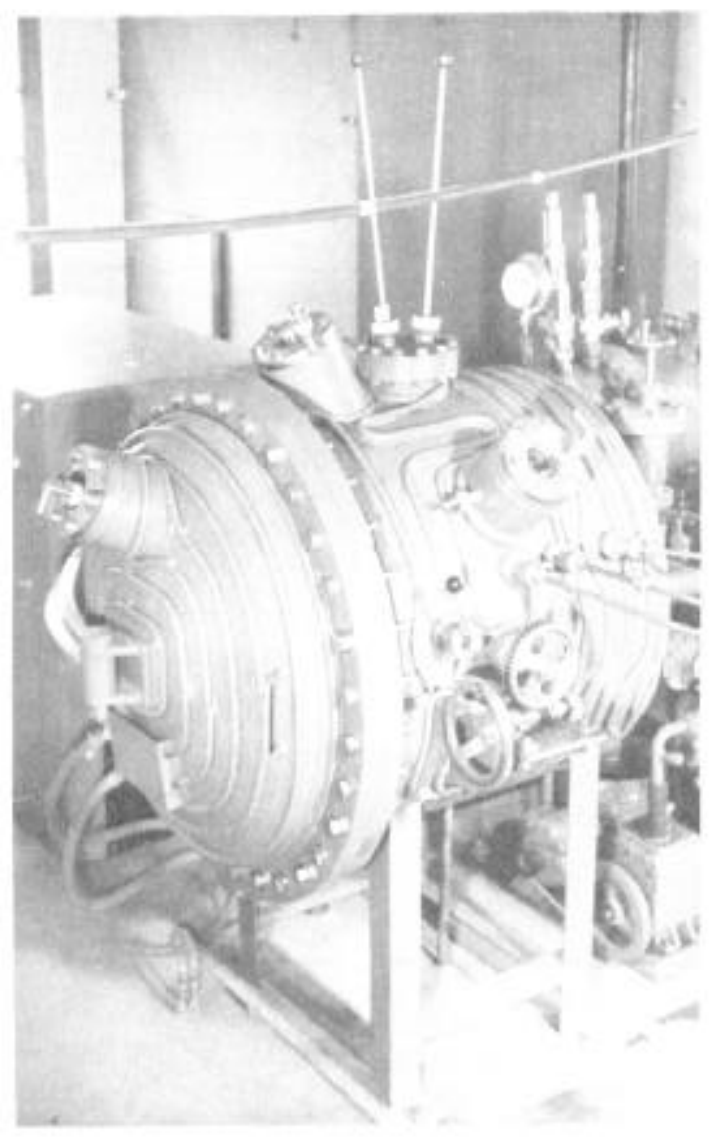

Figure 1. The main part of the high-pressure melting furnace. 
height, and $45 \mathrm{~mm}$ in wall thickness.

\section{Experimental Results}

Nitrogen Solubility in Steels with High Chromium Concentration and Effect of High-Pressure of Nitrogen

It has been known that, in $\mathrm{Fe}-\mathrm{Cr}$ alloys, the nitrogen solubility is remarkably increased with increase of $\mathrm{Cr}$ concentration in every phase of $\gamma, \delta$ and the molten state $[10 \sim 12]$. The temperature coefficient of nitrogen solubility in both the $\gamma$-phase and the molten state proved to be negative. And the nitrogen solubility was somewhat less in the $\delta$-phase that has been primarily crystallized on solidification from the molten state than in both liquid phase and $\gamma$-phase. This is one of the reason why a sound steel ingot of high nitrogen concentration is difficult to be obtained by the ordinary method. On the other hand, when melting and casting are performed under high-pressure nitrogen, the nitrogen solubility in the molten state is remarkably increased; at the same time, the nitrogen, being a $\gamma$-forming element, makes easy a primary crystallization of $\gamma$-phase on solidification; and a casting and melting under suppression of gas evolving under high-pressure expectedly should facilitate the obtaining of a sound steel ingot. Moreover, the nitrogen solubility in $\gamma$-phase is remarkably enhanced with decreasing of temperature. It is thus supposed that the steel with high nitrogen concentration solidified without once generating blowholes presents no opportunity for nitrogen to evolve from the inside to the outside of the steel even if it is subjected to forging or heat treatment after heating to high temperature under atmospheric pressure. Herein lies the significance of a high-pressure melting.

By the way, with respect to the relations between the nitrogen solubility $(\% N)$ in molten iron and the nitrogen partial pressure $\left(\mathrm{p}_{\mathrm{N}_{2}}\right)$ in the atmosphere, Sieverts gave the following formula [5]:

$$
\% N=K\left(p_{N_{2}}\right)^{1 / 2}, \text { where } K=\text { constant }
$$

Kasamatsu and Matoba [13] stated that the nitrogen solubility in molten pure iron will not follow the Sieverts' law when the $\mathrm{p}_{\mathrm{N}_{2}}$ is below $2.3 \mathrm{~atm}$ and Humbert and Elliot [11] reported that this law will hold true with the pure iron and $\mathrm{Fe}-\mathrm{Cr}$ alloys with chromium content up to $57 \%$ in the range of $0.5-1.1 \mathrm{~atm}$ nitrogen. Moreover, Kurochklin [14] described that the $n$ in the undermentioned formula will be increased from 0.5 in the pure iron to 1.02 in $50 \%$ Cr-Fe alloy:

$$
\% N=K\left(p_{N_{2}}\right)^{n}
$$

As stated above there are diverse opinions in accordance with different research even under a low pressure of $\mathrm{p}_{\mathrm{N}_{2}} \leqslant 2.3 \mathrm{~atm}$ in respect to whether the nitrogen solubility in molten iron shall follow the Sieverts' law. Moreover, nothing has been made clear with regard to the nitrogen solubility under a high pressure in the range of $10 \mathrm{~atm}$. Therefore, the authors investigated the effect of $\mathrm{p}_{\mathrm{N}_{2}}$ on nitrogen solubility in the range from a low pressure to $10 \mathrm{~atm}$ with $316 L$ type steels.

From the experimental results, it has been found that the total $\% \mathrm{~N}$ was increased as the molten metal holding time during melting was prolonged, while the $\% \mathrm{~N}$ nearly reached an equilibrium value at the holding time of about $1 \mathrm{~h}$. The total $\% \mathrm{~N}$ value in the case of $1 \mathrm{~h}$ holding at about $1550^{\circ} \mathrm{C}$ under respective pressure of $\mathrm{p}_{\mathrm{N}_{2}}$ being 1, 4, 7 and 10 atm is plotted against $\sqrt{\mathrm{p}_{\mathrm{N}_{2}}}$ in Figure 2. It is known from this figure that $\% N^{2}$ and $\sqrt{\mathrm{p}_{\mathrm{N}_{2}}}$ stand in a linear relationship and follow Sievers' law. In other words, in the formula:

$$
\% N-K\left(p_{N_{2}}\right)^{1 / 2}
$$

the value of $K$ is obtained from each observed value by the method of least squares as follows:

$$
K=0.183 \text {. }
$$

From these results, it is supposed that Sieverts' law almost applies between the saturated nitrogen solubility at about $1550^{\circ} \mathrm{C}$ and the atmospheric nitrogen pressure with $316 \mathrm{~L}$ type molten steel within the range up to about 10 atm in the present experiment.

\section{Soundness of Steel Ingots}

In the aforementioned high-pressure melting of $316 \mathrm{~L}$ type steels, sound ingots always free from blowholes were obtained under every melting condition. As stated before, generally in the case of solidification on primary crystallization of $\delta$-phase, and if the $\mathrm{N}$ concentration in molten steel is larger than the saturated nitrogen solubility in $\delta$ phase, the nitrogen is evolved in the form of gas on solidification and unsound steel ingots with blow holes are obtained. Besides, even in the case of a solidification in the form of primary crystallization of $\gamma$-phase and if the saturated nitrogen solubility is less than the nitrogen concentration in molten steel, unsound ingots also would be produced. Moreover, the nitrogen solubility in steel much depends on the alloy composition and the solidification process of molten steel also is different in accordance with the composition of alloys including nitrogen. Thus, whether the steel ingot becomes sound or unsound will be decided delicately by various complex conditions.

In order to make clear the basic relationship with respect to these facts, at first some $\mathrm{Cr}$ in a range of 10 $25 \%$ was added to $20 \% \mathrm{Ni}-\mathrm{Fe}$ alloys that were held for $20 \mathrm{~min}$ in $4 \mathrm{~atm}$ nitrogen and cast into ingots, of which the relation between chromium and nitrogen concentration versus the soundness was examined. In melting of 


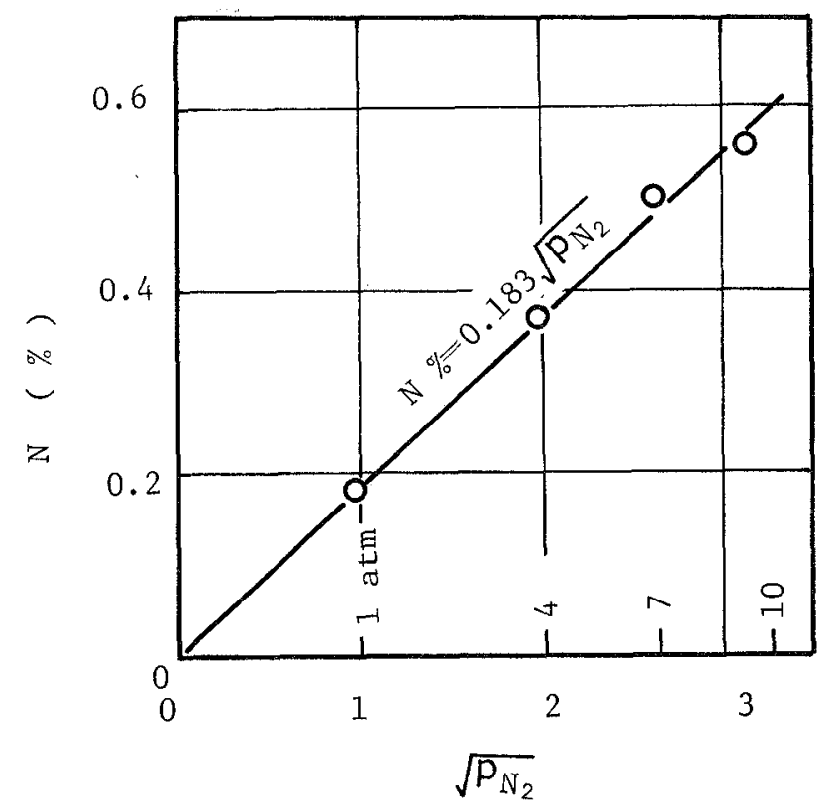

Figure 2. Relation between $\mathrm{N}_{2}$-pressure and nitrogen content of type $316 \mathrm{~L}$ steels melted at about $1,550^{\circ} \mathrm{C}$ for $1 \mathrm{hr}$. 
Table 1. Results of the high-pressure melting in nitrogen atmosphere of $20 \% \mathrm{Ni}-\mathrm{Cr}-\mathrm{Fe}$ alloys

\begin{tabular}{|c|c|c|c|c|c|c|c|c|c|}
\hline \multirow{2}{*}{$\begin{array}{l}\text { Alloy } \\
\text { No. }\end{array}$} & \multirow{2}{*}{$\begin{array}{l}\text { Amount of } \\
\text { Cr added } \\
\langle \%\rangle\end{array}$} & \multirow{2}{*}{$\begin{array}{c}\text { Melting } \\
\text { conditions }\end{array}$} & \multicolumn{6}{|c|}{ Chemical composition (\%) } & \multirow{2}{*}{$\begin{array}{l}\text { Soundness } \\
\text { of ingots }\end{array}$} \\
\hline & & & C & $\mathrm{Si}$ & $M n$ & $\mathrm{Cr}$ & $\mathrm{Ni}$ & Total N & \\
\hline 30 & 10 & \multirow{4}{*}{ a) } & 0.006 & 0.28 & 0.94 & 9.77 & 19.79 & 0.153 & Porous \\
\hline 32 & 15 & & 0.003 & 0.38 & 0.97 & 14.47 & 20.11 & 0.230 & Sound \\
\hline 33 & 20 & & 0.003 & 0.33 & 0.98 & 19.90 & 19.94 & 0.355 & Sound \\
\hline 34 & 25 & & 0.003 & 0.32 & 0.99 & 24.40 & 20.00 & 0.486 & Sound \\
\hline 31 & 10 & b) & 0.003 & 0.28 & 0.96 & 9.82 & 20.01 & 0.186 & Sound \\
\hline
\end{tabular}

a) Held at $1,550^{\circ} \mathrm{C}$ in 4 atm nitrogen atmosphere for $30 \mathrm{~min}$. followed by casting under the same pressure of nitrogen

b) Held at $1,550^{\circ} \mathrm{C}$ in $4 \mathrm{~atm}$ nitrogen atmosphere for $25 \mathrm{~min}$. followed by casting in 10 atm nitrogen atmosphere

Table 2. Results of the high-pressure melting of $10 \% \mathrm{Cr}-20 \% \mathrm{Ni}-\mathrm{Fe}$ alloys

\begin{tabular}{|c|c|c|c|c|c|c|c|c|}
\hline \multicolumn{2}{|c|}{ Melting conditions } & \multicolumn{6}{|c|}{ Chemical composition (\%) } & \multirow{2}{*}{$\begin{array}{l}\text { Soundness } \\
\text { of ingots }\end{array}$} \\
\hline $\begin{array}{c}\mathrm{N}_{2} \text { pressure } \\
\text { (atm) }\end{array}$ & $\begin{array}{c}\text { Holding } \\
\text { time (min.) }\end{array}$ & $\mathrm{C}$ & $\mathrm{Si}$ & $\mathrm{Mn}$ & $\mathrm{Cr}$ & $\mathrm{Ni}$ & Total N & \\
\hline & 10 & 0.003 & 0.31 & 0.97 & 9.89 & 19.20 & 0.155 & Sound \\
\hline \multirow[t]{3}{*}{4} & 20 & 0.002 & 0.38 & 0.99 & 9.89 & 20.02 & 0.156 & Porous \\
\hline & 30 & 0.006 & 0.28 & 0.94 & 9.77 & 19.79 & 0.153 & Porous \\
\hline & 10 & 0.001 & 0.09 & 0.79 & 12.55 & 19.08 & 0.233 & Sound \\
\hline \multirow[t]{2}{*}{10} & 20 & 0.003 & 0.33 & 0.98 & 9.98 & 19.84 & 0.240 & Porous \\
\hline & 30 & 0.009 & 0.24 & 0.93 & 10.66 & 19.81 & 0.268 & Porous \\
\hline
\end{tabular}




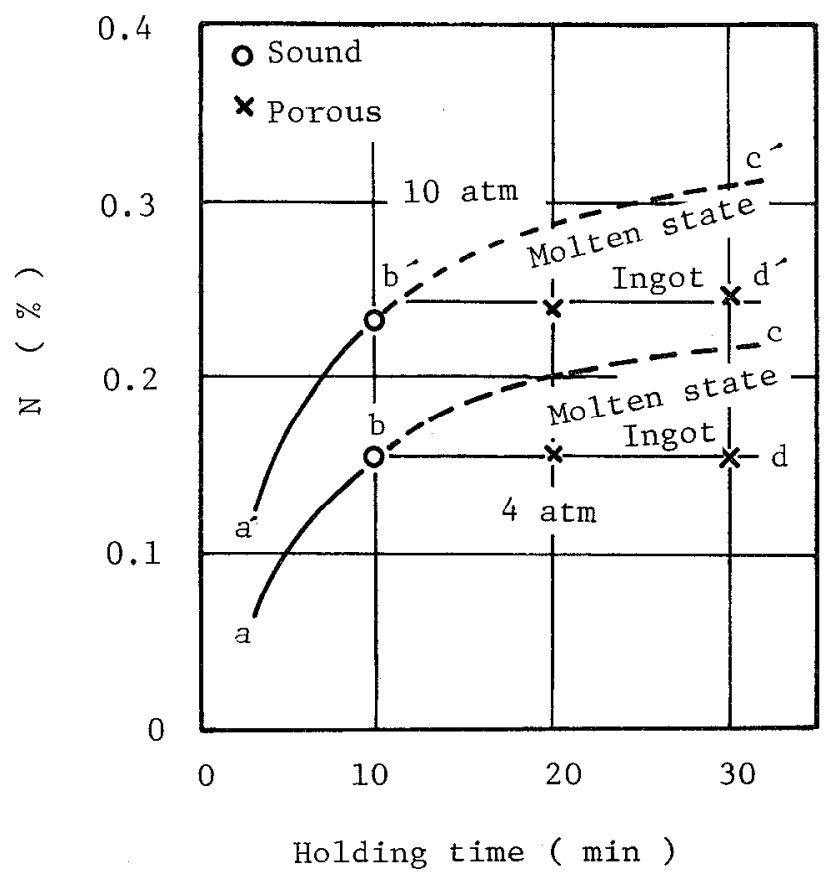

Figure 3. Effect of holding time of molten $10 \% \mathrm{Cr}-20 \% \mathrm{Ni}-\mathrm{Fe}$ alloys under high-pressure nitrogen almosphere on nitrogen content of alloys and on ingot soundness.

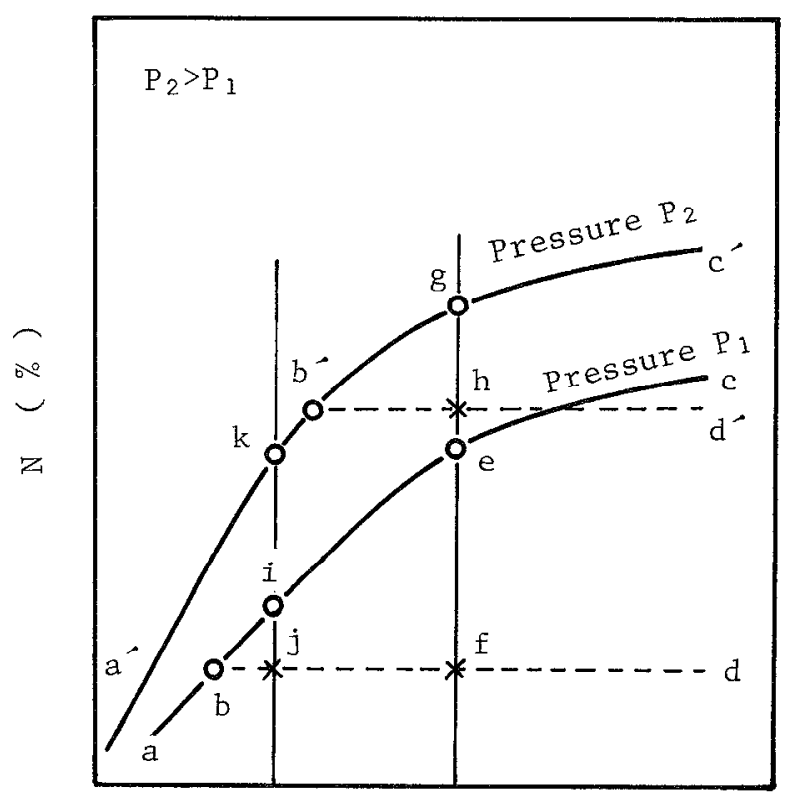

Holding time

Figure 4. Schematic diagram illustrating the correlation between the nitrogen content of a steel in molten state, that in cast state and the holding time of the melt under the nitrogen atmosphere. 
such alloys $0.5 \% \mathrm{Si}$ and $1.0 \% \mathrm{Mn}$ were added as deoxidizers besides $\mathrm{Cr}$ and $\mathrm{Ni}$. Chemical analyses of these stecl ingots are shown in Table 1.

Within the range of $15-25 \% \mathrm{Cr}$, the $\mathrm{N} \%$ was remarkably increased in parallel with the increase of $\mathrm{Cr} \%$ and sound ingots were always obtained, while $10 \% \mathrm{Cr}$ addition caused blow holes and also the $\mathrm{N}$ concentration of steel ingots was no more than $0.153 \%$. However, when the similar $10 \% \mathrm{Cr}$ alloy which had been held for 25 $\mathrm{min}$ at $4 \mathrm{~atm}$, had come in contact with more nitrogen introduced and pressurized up to $10 \mathrm{~atm}$ for about $3 \mathrm{~min}$ and immediately was cast (No. 31 alloy), it showed a sound ingot containing $0.186 \% \mathrm{~N}$. In other words, even in the case of $10 \% \mathrm{Cr}$, a sound ingot might be obtained if the $\mathrm{N}_{2}$ pressure in atmospheres had been sufficiently great in contrast with the $\mathrm{N}$ concentration in molten steel.

Then, with such $10 \% \mathrm{Cr}-20 \%$ Ni-Fe alloys, the holding time was changed in nitrogen at $4 \mathrm{~atm}$ and $10 \mathrm{~atm}$ and, after casting under such pressures as they were, the soundness of ingots was examined. The results are summarized in Table 2. The relationship between the holding time and the $\mathrm{N} \%$ in ingots is shown in Figure 3.

Sound ingots were obtained by holding for $10 \mathrm{~min}$ both at $4 \mathrm{~atm}$ and $10 \mathrm{~atm}$, while unsound ingots with many pores were obtained by holding for $20 \mathrm{~min}$ and 30 min. As shown in Figure 3, the $\mathrm{N}$ concentration in molten steel was presumed to be increased along a tendency of $a-b-c$ at $4 \mathrm{~atm}$, and $a^{\prime}-b^{\prime}-c^{\prime}$ at $10 \mathrm{~atm}$. However, when the concentration was increased above $b$ or $b^{\prime}$, the nitrogen would be issued in gas form on solidification and the $N$ concentration in steel ingols would show a fixed value to be decided by the nitrogen pressure in atmosphere such as bd and $b^{\prime} d{ }^{\prime}$ regardless of the $N$ concentration in molten steel.

Figure 4 is an illustration of these relationships. In the figure, the relationship between $a b c, a^{\prime} b^{\prime} c^{\prime}$ and bd, $\mathbf{b}^{\prime} \mathbf{d}^{\prime}$ are similar to the case in Figure 3. When the $\mathrm{N} \%$ in molten steel is increased to above $b$ in the case of low pressure $P_{1}$ or above $b^{\prime}$ in the case of high pressure $P_{2}$ blow holes occur on solidification and the $\mathrm{N} \%$ in steel ingots is decreased respectively down to bd and ' $b^{\prime} d^{\prime}$. For example, a molten steel with an $\mathrm{N}$ concentration of " $\mathrm{e}$ " is cast under a pressure as it is, the N\% in ingots is reduced to " $\mathrm{f}$ " and " $\mathrm{g}$ " is decreased to " $\mathrm{h}$ ". However, when a molten steel with $\mathrm{N}$ concentration of " $\mathrm{i}$ " is directly cast under a pressure $\mathrm{P}_{1}$, blow holes occur and the $\mathrm{N} \%$ in steel ingots becomes " $\mathrm{j}$ ". However, when the pressure of the atmosphere has been increased to the pressure $P_{2}$ in a short time and the steel has been immediately cast, a sound ingot may be obtained because the $\mathrm{N} \%$ is lower than the limit $b^{\prime}$ between soundness and unsoundness at the pressure $P_{2}$. It is based on this reason why a sound ingot has been obtained by holding the $10 \% \mathrm{Cr}-$ $20 \% \mathrm{Ni}-\mathrm{Fe}$ alloy (as shown in the preceding Table 1) for
$25 \mathrm{~min}$ at $4 \mathrm{~atm}$ and then increasing the pressure up to $10 \mathrm{~atm}$ followed by casting.

Table 3 shows the results of high-pressure melting of $17-4 \mathrm{PH}$ steel and $13 \% \mathrm{Cr}$ heat-resisting steel.

In the case of $17-4 \mathrm{PH}$ steel with $3 \% \mathrm{Si}$, and when the steel has been held for $30 \mathrm{~min}$ at 4 atm and directly cast, the unsound steel ingot is obtained even if the $N$ concentration in ingots is $0.27 \%$. On the contrary, when the steel has been held for $25 \mathrm{~min}$ at $4 \mathrm{~atm}$, then pressurized up to $10 \mathrm{~atm}$ and immediately cast, a sound ingot even with $0.35 \% \mathrm{~N}$ is obtained. The results of this case corresponds to the aforementioned results. Besides, as shown in Table 3, the steel with $3 \% \mathrm{Si}$ added to $17-4 \mathrm{PH}$ steel becomes unsound after holding for $30 \mathrm{~min}$ at 4 atm before casting, while it becomes sound after holding 30 $\mathrm{min}$ at $10 \mathrm{~atm}$ before casting. In the latter case, it is presumably because the $\mathrm{N} \%$ in molten steel has been increased and much $\gamma$-phase has been crystallized out during solidification.

Moreover, the steel with $0.5 \% \mathrm{Si}$ added and cast after holding for $30 \mathrm{~min}$ at $4 \mathrm{~atm}$ can give a sound ingot even if it contains more $\mathrm{N} \%$ than in the case of $3 \% \mathrm{Si}$. The reason is because $\mathrm{Si}$ is a ferrite-forming element as well as an element reducing the $\mathrm{N}$ solubility in molten steel [12], and because the less $\mathrm{Si}$ the more the $\mathrm{N} \%$ in molten steel even under the same melting conditions thus facilitating the development of $\gamma$-phase during solidification.

Table 4 shows the results of high-pressure melting of some high $\mathrm{Cr}-\mathrm{Fe}$ alloys all giving sound ingots. As shown in this Table, ever under the same melting conditions, $18 \% \mathrm{Cr}-10 \% \mathrm{Mn}$ steel contained more $\mathrm{N} \%$ than $18 \% \mathrm{Cr}-$ $4 \% \mathrm{Ni}$ steel, and $22 \% \mathrm{Cr}-2 \% \mathrm{Ni}$ steel included more $\mathrm{N} \%$ than $22 \% \mathrm{Cr}$ steel. Besides, with $20 \% \mathrm{Cr}-20 \% \mathrm{Ni}-\mathrm{Fe}$ alloy as the basic series of LCN-155, it is known that the more Co added in the same $10 \mathrm{~atm}-10 \mathrm{~min}$-melting, the less the $\mathrm{N} \%$ becomes. Besides, in the case when an alloy charge of $60 \% \mathrm{Cr}-40 \% \mathrm{Fe}$ had been cast after holding for 30 $\min$ at $10 \mathrm{~atm}$, the $\mathrm{N}$ on solidification reached $2.79 \%$ at the $\mathrm{Cr}$ content of $51.74 \%$.

Plastic Workability, Machinability and Weldability of Steel Melted and Cast under High-Pressure Nitrogen

The aforementioned various steel ingots melted under high pressure showed a bit more difficulty generally in forging as the $\mathrm{N}$ concentration was increased. Nevertheless, they proved the full possibility of being extended from a $60 \mathrm{~mm}$ square ingot into a $15 \mathrm{~mm}$ square billet as well as the possibility of hot and cold workability into far smaller sections.

In addition, with respective steel types no particular difficulty was observed in machining operations such as turning, sawing, shaping and milling. 
Table 3. Results of high-pressure melting in nitrogen atmosphere of $17-4 \mathrm{PH}$ and $13 \% \mathrm{Cr}$ steels

\begin{tabular}{|c|c|c|c|c|c|c|c|c|c|c|c|c|}
\hline \multirow[b]{2}{*}{ No. } & \multirow[b]{2}{*}{$\begin{array}{l}\text { Steel } \\
\text { type }\end{array}$} & \multicolumn{2}{|c|}{ Melting conditions } & \multirow{2}{*}{$\begin{array}{l}\text { Pressure of } \\
\text { nitrogen in } \\
\text { casting } \\
\text { (atm) }\end{array}$} & \multicolumn{7}{|c|}{ Chemical composition $(\%)$} & \multirow{2}{*}{$\begin{array}{l}\text { Soundness } \\
\text { of ingots }\end{array}$} \\
\hline & & $\begin{array}{l}\text { Pressure of } \\
\text { nitrogen } \\
\text { (atm) }\end{array}$ & $\begin{array}{l}\text { Holding } \\
\text { time (Iriii) }\end{array}$ & & c & $\mathrm{Si}$ & $\mathrm{Mn}$ & $\mathrm{Cr}$ & $\mathrm{Ni}$ & $\mathrm{Cu}$ & $\begin{array}{c}\text { Total } \\
\mathrm{N}\end{array}$ & \\
\hline 49 & $\begin{array}{c}17-4 \mathrm{PH} \\
\text { type } \\
\text { with } \\
3 \% \mathrm{Si}\end{array}$ & 4 & 10 & 4 & 0.005 & 2.92 & 0.57 & 17.42 & 4.07 & 3.60 & 0.22 & Sound \\
\hline 22 & & 4 & 30 & 4 & 0.009 & 3.07 & 0.48 & 16.85 & 4.06 & 4.00 & 0.27 & Porous \\
\hline 29 & & 4 & 25 & 10 & 0.016 & 2.85 & 0.48 & 16.74 & 4.45 & 4.00 & 0.35 & Sound \\
\hline 21 & & 30 & 30 & 10 & 0.004 & 2.80 & 0.47 & 15.84 & 4.35 & 4.01 & 0.44 & Sound \\
\hline 28 & $\begin{array}{c}17-4 \mathrm{PH} \\
\text { type } \\
\text { with } \\
0.5 \% \mathrm{Si}\end{array}$ & 4 & 30 & 4 & 0.015 & 0.40 & 0.47 & 16.76 & 4.43 & 3.96 & 0.37 & Sound \\
\hline $05 N$ & & 1 & 30 & 1 & 0.01 & 0.20 & 0.74 & 12.95 & - & $\cdot$ & 0.054 & 4 Sound \\
\hline $25 \mathrm{~N}$ & & 4 & 30 & 4 & 0.01 & 0.43 & 0.97 & 12.67 & - & - & 0.246 & 6 Porous \\
\hline $35 \mathrm{~N}$ & $13 \mathrm{Cr}$ & 4 & 30 & 10 & 0.01 & 0.45 & 0.92 & 12.73 & - & - & 0.346 & 3 Porous \\
\hline $26 \mathrm{~N}$ & & 4 & 5 & 10 & 0.01 & 0.33 & 0.75 & 12.90 & - & - & 0.263 & 3 Sound \\
\hline $38 \mathrm{~N}$ & & 10 & 30 & 10 & 0.01 & 0.38 & 0.89 & 12.87 & - & - & 0.380 & Porous \\
\hline
\end{tabular}


Table 4. Results of the high-pressure melting in nitrogen atmosphere of some stainless and heat-resisting steels

\begin{tabular}{|c|c|c|c|c|c|c|c|c|c|c|}
\hline \multirow{2}{*}{$\begin{array}{c}\text { Types } \\
\text { of } \\
\text { steel }\end{array}$} & \multicolumn{2}{|c|}{ Melting conditions } & \multicolumn{8}{|c|}{ Chemical composition (\%) } \\
\hline & $\mathrm{N}_{2} \underset{\text { (atm) }}{\text { pressure }}$ & $\begin{array}{l}\text { Holding } \\
\text { time (min.) }\end{array}$ & C & $\mathrm{Si}$ & $M n$ & $\mathrm{Cr}$ & $\mathrm{Ni}$ & Co & Others & $\begin{array}{c}\text { Total } \\
\mathrm{N}\end{array}$ \\
\hline \multirow[t]{2}{*}{$18 \mathrm{Cr}-4 \mathrm{Ni}$} & 1 & 10 & 0.006 & 0.37 & 0.92 & 18.15 & 3.95 & - & - & 0.090 \\
\hline & 10 & 10 & 0.005 & 0.38 & 0.97 & 18.17 & 4.13 & - & - & 0.592 \\
\hline \multirow{5}{*}{$18 \mathrm{Cr}-10 \mathrm{Mn}$} & 1 & 10 & 0.005 & 0.38 & 10.45 & 17.89 & - & - & - & 0.136 \\
\hline & 4 & 10 & 0.003 & 0.36 & 10.70 & 17.96 & - & - & - & 0.459 \\
\hline & 7 & 10 & 0.004 & 0.35 & 10.50 & 18.04 & - & - & - & 0.656 \\
\hline & 7 & 30 & 0.005 & 0.41 & 10.55 & 18.14 & - & - & - & 0.772 \\
\hline & 10 & 30 & 0.005 & 0.41 & 10.60 & 17.22 & 0.01 & - & - & 0.959 \\
\hline $22 \mathrm{Cr}$ & 10 & 10 & 0.004 & 0.33 & 0.90 & 22.16 & - & - & - & 0.485 \\
\hline $22 \mathrm{Cr}-2 \mathrm{Ni}$ & 10 & 10 & 0.003 & 0.32 & 0.90 & 21.98 & 2.00 & - & - & 0.561 \\
\hline \multirow{6}{*}{ LCN-155 } & 10 & 10 & - & - & 1.05 & 19.29 & 19.17 & - & - & 0.355 \\
\hline & 10 & 10 & - & - & 0.96 & 19.21 & 19.53 & 9.10 & - & 0.338 \\
\hline & 10 & 10 & - & - & 0.92 & 19.17 & 18.62 & 19.62 & - & 0.280 \\
\hline & 1 & 30 & 0.006 & 0.09 & 1.14 & 19.72 & 19.93 & 19.69 & Mo 3.00 & 0.269 \\
\hline & & & & & & & & & W 2.45 & \\
\hline & & & & & & & & & $\mathrm{Nb} 0.96$ & \\
\hline $60 \mathrm{Cr}-\mathrm{Fe}$ & 10 & 30 & 0.078 & 0.054 & 0.057 & 51.74 & - & - & - & 2.79 \\
\hline
\end{tabular}


Spot weldability and arc weldability have also been investigated with an $18 \% \mathrm{Cr}-10 \% \mathrm{Mn}$ type steel containing high concentration of nitrogen up to about $0.8 \%$. Both of welding methods gave a very good and sound weld, if ordinary welding conditions recommended for welding of commercial austenitic stainless steels are adopted. The spot weldability of the steels scarcely depended upon nitrogen concentration, and was about the same as that of commercial austenitic stainless steels. But, in the steel containing higher concentration of nitrogen, i.e., more than $0.5 \%$, a small number of expulsions and blowholes in the weld nugget could be detected. Therefore, in case of welding such a steel, better properties of the nugget will be obtained by adjusting welding condition to prevent them. The nitrogen in base metals scarcely diffused out of the nugget even in the steel containing about $0.8 \%$ nitrogen. Consequently, the spot weld shear strength rose in proportion to the increase in nitrogen content and any decrease of it did not occur on account of nitrogen diffusion.

In the arc welding, a part of nitrogen, which had been contained in base metal, evolved into atmosphere and also a part of that diffused out to the weld deposit. The decrease of the nitrogen concentration in base metal, however, is considered to be not so much. And hardness and tensile strength of the weld increased with increasing nitrogen content in base metals. As the nitrogen content of the base metals, increased, and as power input for the arc welding increased, some blowholes tend to be included in the deposit metal, and the density of them became considerable when the nitrogen content of the base metals exceeds $0.65 \%$, so that, it has been concluded that a reliability of the weld bond in such higher nitrogen steels are somewhat decreased and the bead apparences are deteriorated.

Investigation on the weldability of $\mathrm{Cr}-\mathrm{Ni}$ austenitic heat-resisting steels containing high concentration of nitrogen has today been continued.

Change of Nitrogen Concentration by High-Temperature Heating with a Steel Melted and Cast in High-Pressure Nitrngen

Even a steel with high- $N$ concentration that had been obtained by high-pressure melting presumably would not be worthy of the significance of high-pressure melting if the $\mathrm{N}$ was diffused and evolved from steel. In order to make clear this point experimentally, with $316 \mathrm{~L}$ type steel containing $0.450 \% \mathrm{~N}$, the weight change during heating to $1,100^{\circ} \mathrm{C}$ in air and in a vacuum was traced, using a thermo-balance, and the change of $\mathrm{N} \%$ before and after heating was obtained by chemical analysis. The specimen had a dimension of $8 \times 55 \times 0.6 \mathrm{~mm}$ and a weight of about $2 \mathrm{~g}$. While heating in vacuum to $1,100^{\circ} \mathrm{C}$ for about $45 \mathrm{~mm}$, it experienced a weight decrease from around $600^{\circ} \mathrm{C}$. This continued even during holding at $1,100^{\circ} \mathrm{C}$. The chemical analysis of the specimen after heating for $3 \mathrm{~h}$ at $1,100^{\circ} \mathrm{C}$ indicated that the $\mathrm{N}$ concentration was decreased from $0.450 \%$ to $0.292 \%$. I he value nearly corresponded with the weight decrease measured by the thermo-balance. After heating in air, however, a remarkable increase in the weight was noted. Most of such an increase presumably was due to oxidation of the specimens. However, in accordance with the results of chemical analysis, the $\mathrm{N}$ concentration was slightly increased from $0.450 \%$ to $0.477 \%$. These results indicate that the steel melted under high pressure showed remarkable denitriding after heating at a high temperature in high vacuum, while no denitriding occurred when it was heated in air, but rather there was a slight tendency to absorb nitrogen.

\section{Creep and Creep-Rupture Properties of Austenitic Heat-Resisting Steels Melted and Cast under High- Pressure Nitrogen}

Creep-rupture tests were made at $700^{\circ} \mathrm{C}$ on the $316 \mathrm{~L}$ steel containing various amounts of nitrogen. Results are shown in Figure 5. The $1,000 \mathrm{hr}$ rupture strength of the steel increases markedly with increasing nitrogen content and is almost doubled at $0.33 \% \mathrm{~N}$, while the strength decreases with further increasing nitrogen content. The later decrease in the strength is attributable to a rapid precipitation of supersaturated nitrogen from the austenite matrix. It has been reported that nitrogen, un like carbon, is one order higher in its solubility in the base austenite [15]. Fiture 6 shows steady state creep ratestress data at $700^{\circ} \mathrm{C}$ for $18 \mathrm{Cr}-14 \mathrm{Ni}$ austenitic steels with or without Mo and N. From this results, a relation between creep strength at the strain rate of $0.1 \% / \mathrm{hr}$ and nitrogen content in the steel are obtained as shown in Figure, and a power law dependence $n$ [16] for creep are as follows:

\begin{tabular}{|c|c|c|c|c|}
\hline & \multicolumn{3}{|c|}{ Composition } & \multirow{2}{*}{$\begin{array}{c}\text { Power law } \\
\text { dependence } n\end{array}$} \\
\hline Mark & $\mathrm{C} \%$ & Total N\% & Mo\% & \\
\hline N1 & 0.015 & 0.017 & 0.01 & 5.8 \\
\hline N2 & 0.004 & 0.264 & 0.01 & 5.5 \\
\hline NM 1 & 0.012 & 0.039 & 2.04 & 8.5 \\
\hline NM2 & 0.002 & 0.277 & 2.10 & 8.0 \\
\hline
\end{tabular}

It is quite clear that nitrogen, dissolved as an interstitial solute in the austenite together with $\mathrm{Cr}$ and Mo, may considerably increase the creep resistance. If, then, nitrogen in excess of about $0.3 \%$, combined with $\mathrm{Cr}, \mathrm{Mu}$, and other elements, can be retained as dissolved for a long time at high temperature for use, it can be anticipated that the strength will be further increased.

Thus, $25 \% \mathrm{Cr}-28 \% \mathrm{Ni}$ was chosen for the base composition of the steel to be developed. $28 \% \mathrm{Ni}$ content was selected in this steel to secure the austenitic phase even when a certain amount of ferrite- or $\sigma$-forming elements such as $\mathrm{Mo}$ and $\mathrm{W}$ are added. $25 \% \mathrm{Cr}$ content was selected 


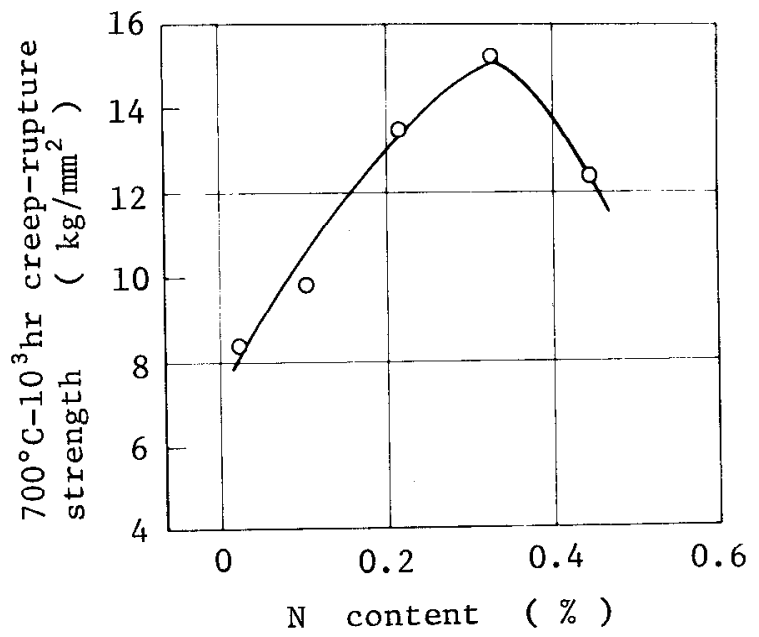

Figure 5. Effect of nitrogen on creep-rupture strength of the type $316 \mathrm{~L}$ steel at $700^{\circ} \mathrm{C}$. 


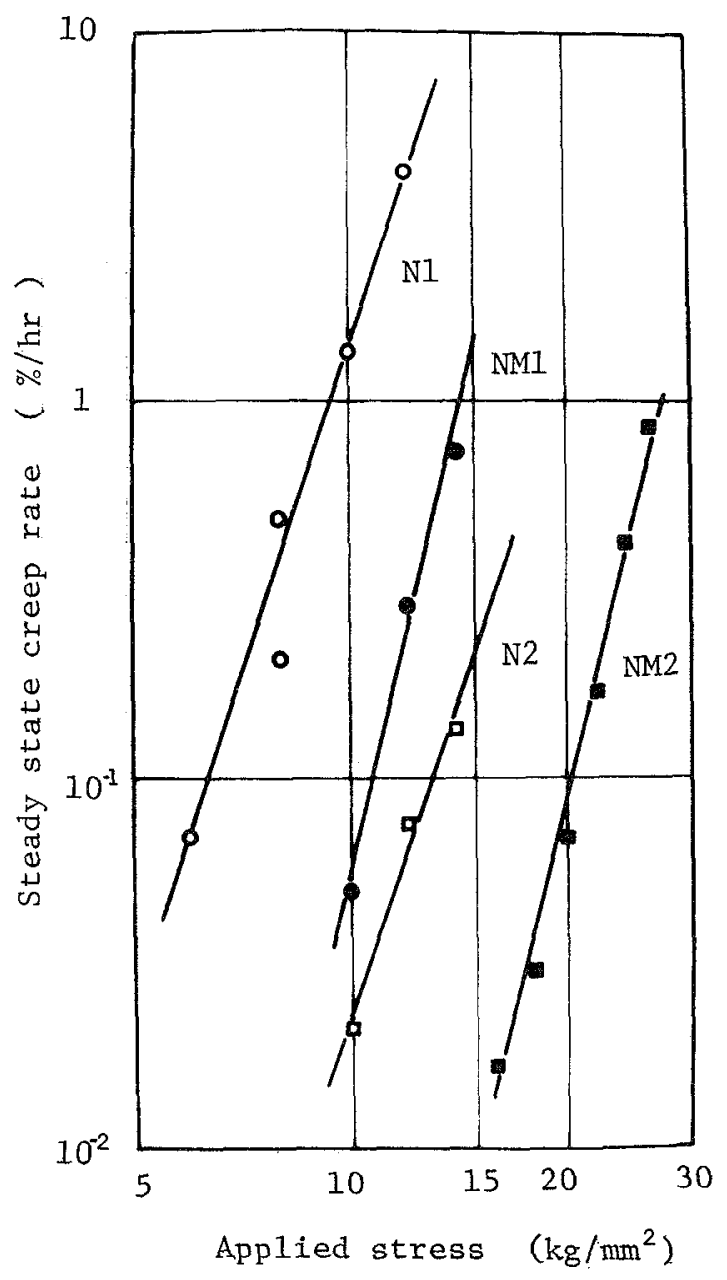

Figure 6. Influence of $\mathrm{Mo}$ and $\mathrm{N}$ on stress-creep rate curve of $18 \% \mathrm{Cr}-14 \% \mathrm{Ni}$ austenitic steel.

\begin{tabular}{cccccc} 
Steel & C $\%$ & Ni $\%$ & Cr $\%$ & Mo $\%$ & Total N \% \\
\hline N1 & 0.015 & 13.36 & 17.08 & 0.01 & 0.017 \\
N2 & 0.004 & 14.08 & 17.94 & 0.01 & 0.264 \\
NM1 & 0.012 & 13.77 & 17.94 & 2.04 & 0.039 \\
NM2 & 0.002 & 14.08 & 17.89 & 2.10 & 0.277
\end{tabular}




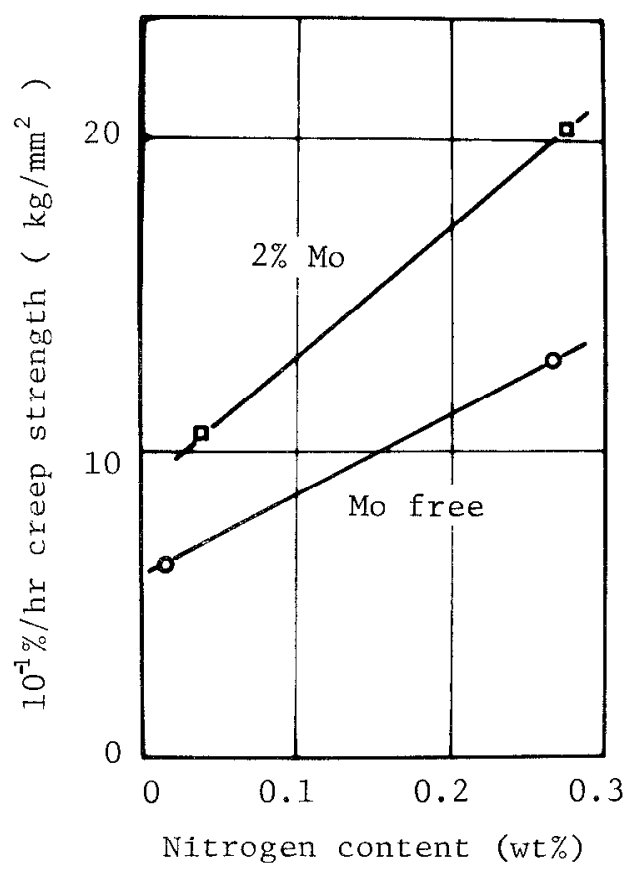

Figure 7. Relation between $10^{-1} \% / \mathrm{hr}$ creep strength and nitrogen content of $18 \% \mathrm{Cr}-14 \% \mathrm{Ni}$ austenitic steel with or without $\mathrm{M}$. 
to promote oxidation resistance at high temperatures such as $700^{\circ} \mathrm{C}$ or above and to secure a high concentration of nitrogen in the steel which is melted and cast under a high-pressure nitrogen atmosphere.

High-pressure melting technique was applied to this $25 \% \mathrm{Cr} 28 \% \mathrm{~N}$ i steel so that nitrogen of up to about $0.54 \%$ could be alloyed. The effects of Mo and $\mathrm{N}$ on the creep rupture strength at $700^{\circ} \mathrm{C}$ are summarized in Figure 8.

In Figure 8(a), the effects of Mo are classified by low nitrogen steel (less than $0.10 \% \mathrm{~N}$ ), medium nitrogen steel $(0.15-0.20 \% N)$ and high nitrogen steel. In the case of low nitrogen and medium nitrogen steels, the increase in strength due to the addition of Mo follows a similar trend. The increment of strength at $6 \% \mathrm{Mo}$ is 5-6 $\mathrm{kg} / \mathrm{mm}^{2}$. However, the effect of Mo in high nitrogen steel shows a different tendency. The strength increases markedly by more than $10 \mathrm{~kg} / \mathrm{mm}^{2}$ with the addition of $2 \%$ Mo. This can be more clearly observed in Figure 8 (b). The effect of nitrogen in about $0.2 \%$ is almost the same, whether Mo is added or not; however, at levels higher than $0.2 \%$, the strength drops sharply in the absence of Mo, while in a steel containing this element the strength increases almost linearly with increasing nitrogen. It is interesting to note here that when $M_{0}$ is added to a high nitrogen steel, a special effect on strength is observed due to the coexistence of Mo and $\mathrm{N}[17,18]$.

In order to obtain some information on the strengthening mechanism in these high nitrogen steels, metallographic and $X$-ray diffraction studies were made. Variation in lattice parameter of austenite matrix due to aging at $700^{\circ} \mathrm{C}$ was measured on two kinds of steels, whose chemical compositions are as follows:

\begin{tabular}{cccccc} 
Mark & $\mathrm{C}$ & $\mathrm{Cr}$ & $\mathrm{Ni}$ & $\mathrm{Mo}$ & $\mathrm{N}$ \\
\hline $22 \mathrm{~N}$ & 0.011 & 26.28 & 27.81 & 1.21 & 0.221 \\
$31 \mathrm{~N}$ & 0.009 & 24.49 & 27.84 & 2.11 & 0.311
\end{tabular}

In the $22 \mathrm{~N}$ steel having $0.22 \% \mathrm{~N}$ and $1.21 \% \mathrm{Mo}$, no parameter change of austenite, that is, no precipitation of nitride, occurs during aging at $700^{\circ} \mathrm{C}$ up to $3,000 \mathrm{hr}$, whereas in $31 \mathrm{~N}$ steel having $0.31 \% \mathrm{~N}$ and $2.11 \% \mathrm{Mo}$, a marked decrease in the parameter occurs. From metallographical examinations, a precipitation of $\sigma$-phase, instead of $\mathrm{Cr}_{2} \mathrm{~N}$, is observed in aged specimens of $21 \mathrm{~N}$ steel, whereas in $31 \mathrm{~N}$ steel a precipitation of $\mathrm{Cr}_{2} \mathrm{~N}$ and $\pi$-phase $(\beta$-Mn structure [19]) is observed both within grains and on grain boundaries or twin boundaries.

It was concluded from these results that, in the high nitrogen steels with Mo, about $0.2 \% \mathrm{~N}$ is retained as dissolved in the austenite matrix for a long period of creep rupture testing even at such high temperatures as $700^{\circ} \mathrm{C}$ and contributes together with Mo to creep rupture strength through the solid solution strengthening mechanism.

In most of the heat-resistant steels, carbon is used as an alloying element for high temperature strengthening. For purposes of comparison, effects of carbon on $25 \% \mathrm{Cr}-$ $28 \% \mathrm{Ni}-2 \%$ Mo steel were investigated. In the case of the specimen solution treated at $1,250^{\circ} \mathrm{C}$, the $700^{\circ} \mathrm{C}-1,000 \mathrm{hr}$ rupture strength rises almost linearly in proportion to the carbon content, reaching $15.5 \mathrm{~kg} / \mathrm{mm}^{2}$ at $0.35 \%$ carbon. This strength is about $2 \mathrm{~kg} / \mathrm{mm}^{2}$ less than when the same weight percent nitrogen is added. In addition, rupture elongation is always greater than $20 \%$ when nitrogen is added, but in the $0.35 \%$ carbon steel solution quenched from $1,250^{\circ} \mathrm{C}$, the elongation is less than $10 \%$.

Experiments were also made in which carbon and nitrogen were added. The $700^{\circ} \mathrm{C}-1,000 \mathrm{hr}$ rupture strength of a steel containing $0.17 \%$ carbon and $0.27 \%$ nitrogen was obtained, and it is noted that the strength at the same level of $\mathrm{Mo}$ and $\mathrm{N}$ is smaller than that of the steels containing less carbon.

It can be said from these results that, in the high nitrogen steel, the addition of carbcn is not required and should be avoided.

In further investigation, a large amount of nitrogen was added in combination with $\mathrm{V}, \mathrm{W}$ and $\mathrm{B}$ to $25 \% \mathrm{Cr}-$ $28 \% \mathrm{Ni}-2 \% \mathrm{Mo}$ steel, then the steel was tested for creep rupture strength at $700^{\circ} \mathrm{C}$. Some of the test results are shown in Figure 9. Steel $31 \mathrm{~N} 22 \mathrm{~W}$ shows an almost linear stress-rupture curve even after the test period of $20,000 \mathrm{hr}$ at $700^{\circ} \mathrm{C}$ and possesses rupture strengths of $23.0 \mathrm{~kg} / \mathrm{mm}^{2}$ in $1,000 \mathrm{hr}$ and $14 \mathrm{~kg} / \mathrm{mm}^{2}$ in $10,000 \mathrm{hr}$. The strengths of steel $31 \mathrm{~N} 22 \mathrm{~W}$ are greater than those of steel $48 \mathrm{~N} 09 \mathrm{~V}$ and $42 \mathrm{NO} 3 \mathrm{~B}$, although nitrogen content in that steel is relatively low. This shows that coexistence of $W$ and $N$ together with Mo contributes remarkably to strengthening. Steel 42N03B has an excellent high temperature ductility. It contains about $0.03 \% \mathrm{~B}$ and has a rupture elongation of more than $60 \%$, which increases with increasing rupture time.

In view of the above facts, combinations of $\mathrm{B}, \mathrm{W}$ and $\mathrm{N}$ were added to $25 \% \mathrm{Cr}-28 \% \mathrm{Ni}-2 \% \mathrm{Mo}$ steel which was then tested. $W$ content was fixed in the range of $5.1-5.7 \%$ to examine the effect of nitrogen. In Figure 10 (a), the rupture strength of $700^{\circ} \mathrm{C}-1,000 \mathrm{hr}$ rises sharply with the addition of nitrogen, reaching a high level of more than $26 \mathrm{~kg} / \mathrm{mm}^{2}$ at a $\mathrm{N}$ level of about $0.67 \%$. Compared with other steels not containing $W$ and $B$ (shown by dotted line), a marked strengthening effect due to the simultaneous addition of $B$ and $W$ is observed in the low concentration range of nitrogen. The rupture strength $\left(700^{\circ} \mathrm{C}-1,000 \mathrm{hr}\right)$ of steel $42 \mathrm{~N} 03 \mathrm{~B}$ is also shown in the figure. It is noted that the strength increment due to $5 \% \mathrm{~W}$ 


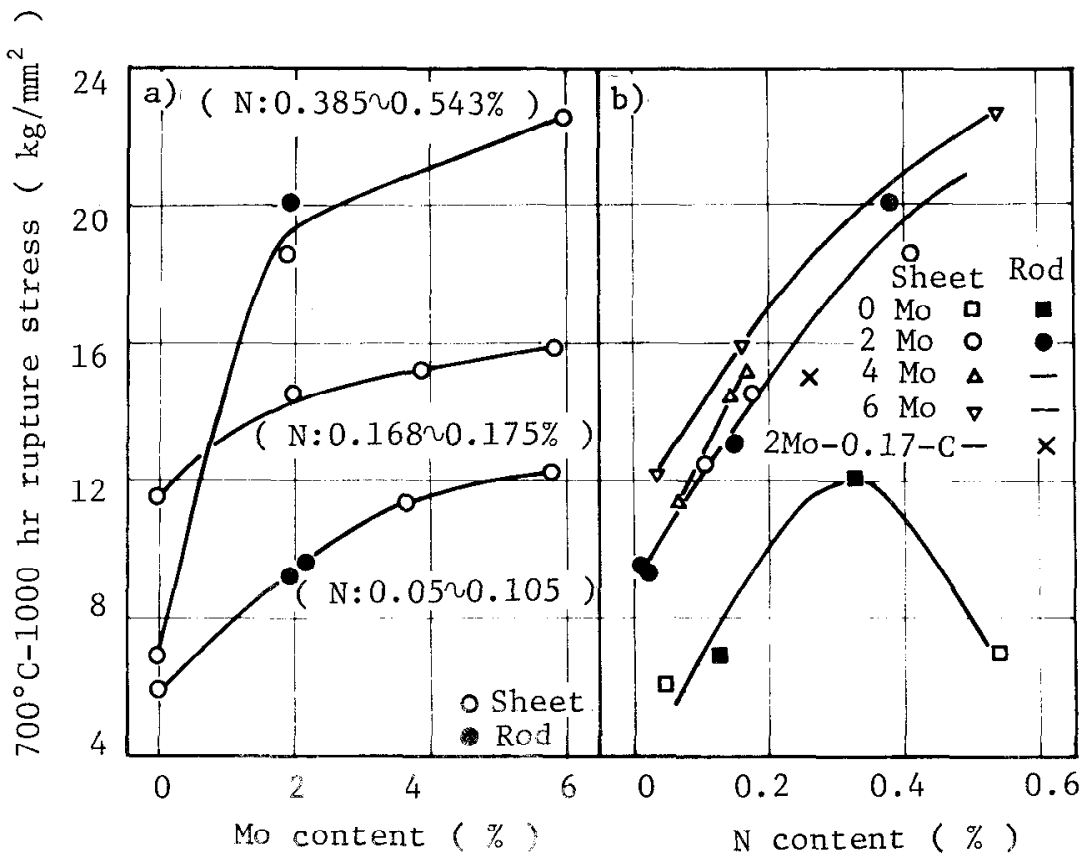

Figure 8. Effect of $\mathrm{Mo}$ and $\mathrm{N}$ on $700^{\circ} \mathrm{C}-1,000 \mathrm{hr}$ creep-rupture strength of the $25 \% \mathrm{Cr}-28 \% \mathrm{Ni}$ austenitic steels (solution treatment : $1,200^{\circ} \mathrm{C}$ )

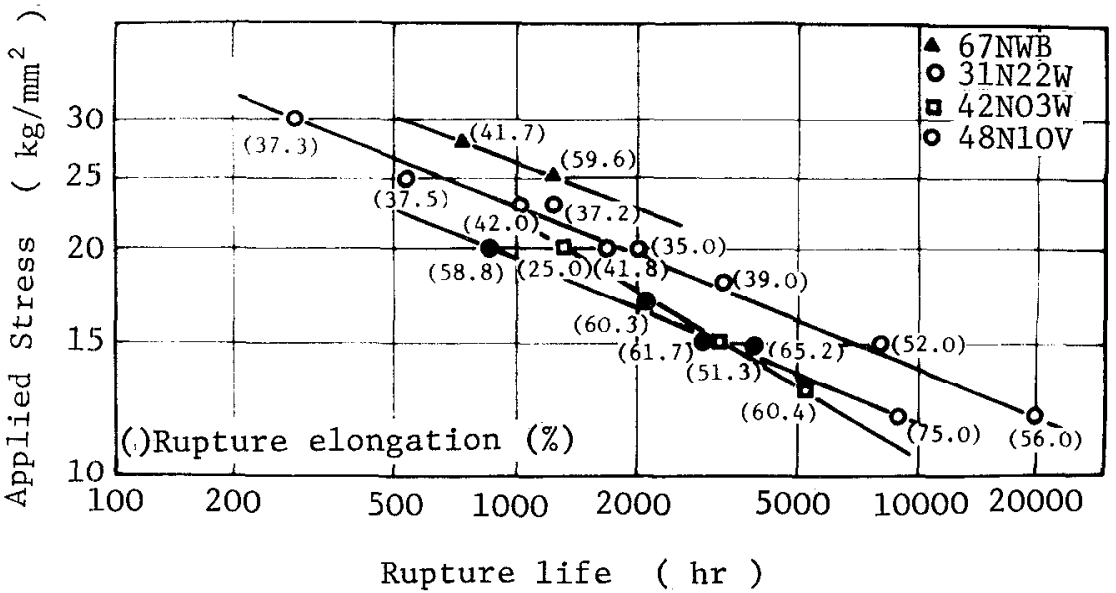

Figure 9. Typical stress-rupture curves at $700^{\circ} \mathrm{C}$ of $25 \% \mathrm{Cr}-28 \% \mathrm{Ni}-2 \% \mathrm{Mo}$ austenitic heat-resisting steel (solution treatment : $1,200^{\circ} \mathrm{C}$ )

\begin{tabular}{lcccccccc}
\multicolumn{1}{c}{ Steel $^{\prime}$} & C $\%$ & Cr $\%$ & Ni \% & Mo \% & W \% & V \% & B \% & Total N \% \\
\hline 31N22W & 0.028 & 23.53 & 26.46 & 1.55 & 2.19 & - & - & 0.307 \\
42N03B & 0.005 & 24.16 & 27.78 & 1.80 & - & - & 0.027 & 0.420 \\
48N09V & 0.028 & 24.45 & 27.65 & 1.55 & - & 0.95 & - & 0.483 \\
67NWB & 0.020 & 24.62 & 27.12 & 1.90 & 5.70 & - & 0.050 & 0.668
\end{tabular}




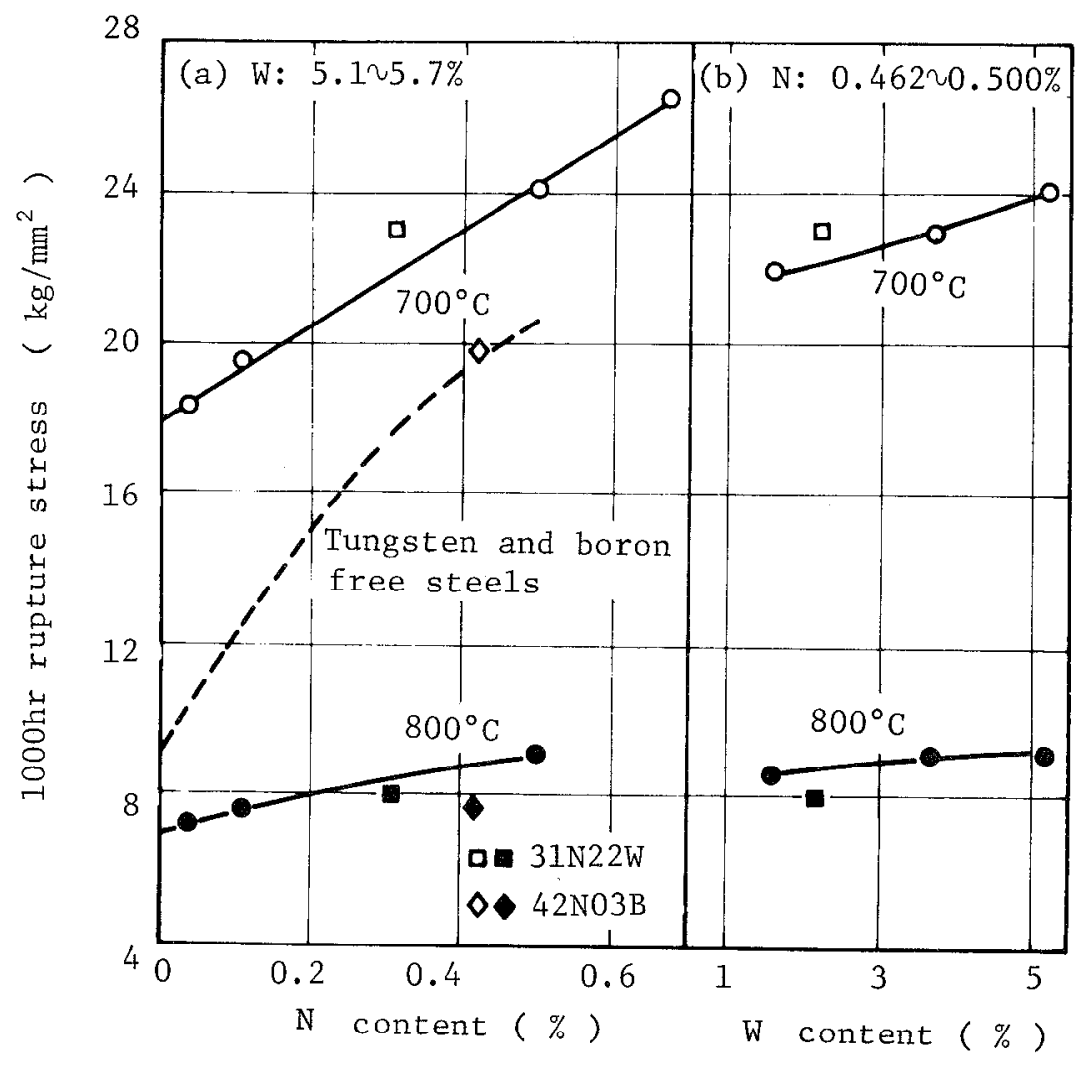

Figure 10. Effect of $\mathrm{N}$ and $\mathrm{W}$ on $1,000 \mathrm{hr}$ creep-rupture strength at $700^{\circ} \mathrm{C}$ and $800^{\circ} \mathrm{C}$ of the $25 \%$ $\mathrm{Cr}-28 \% \mathrm{Ni}-2 \% \mathrm{Mo}-0.05 \% \mathrm{~B}$ steels (solution treatment : $1,200^{\circ} \mathrm{C}$ ) 
is about $3.5 \mathrm{~kg} / \mathrm{mm}^{2}$ in the neighborhood of $0.42 \% \mathrm{~N}$. Also indicated in the figure is the strength of steel $31 \mathrm{~N} 22 \mathrm{~W}$. Here, at $700^{\circ} \mathrm{C}$, steel containing low $\mathrm{W}$ (steel $31 N 22 W$ ) shows a slightly higher strength than that containing high $W$, while the reverse is true for $800^{\circ} \mathrm{C}-$ $1,000 \mathrm{hr}$. At $800^{\circ} \mathrm{C}$, as at $700^{\circ} \mathrm{C}$, the strength of a steel in which $W$ and $B$ coexist is improved by the addition of nitrogen. An increment of about $2 \mathrm{~kg} / \mathrm{mm}^{2}$ is brought about by the addition of $0.5 \%$ nitrogen. As shown in Figure 10(b), at a fixed level of nitrogen, the rupture strength increases almost linearly with the addition of $W$, both at $700^{\circ} \mathrm{C}$ and $800^{\circ} \mathrm{C}$, but this effect is not as pronounced as is observed in Figure 10(a) when the nitrogen content is changed.

The minimum value of creep rupture elongation encountered in these experiments was not less than $20 \%$, showing that these steels generally have a good high temperature ductility. Steels containing B particularly have an excellent ductility.

When, as described above, Mo, $W, V$ and $B$ are added in various combinations, with $25 \% \mathrm{Cr}-28 \% \mathrm{Ni}$ steel as the base, and with the use of the high-pressure melting technique, the $700^{\circ} \mathrm{C}-1,000 \mathrm{hr}$ creep rupture strength far exceeds $20 \mathrm{~kg} / \mathrm{mm}^{2}$, and the high temperature ductility is also greatly improved. Of the $25 \% \mathrm{Cr}-28 \% \mathrm{Ni}$ steels tested, those which have $700^{\circ} \mathrm{C}-1,000 \mathrm{hr}$ rupture strength far stronger than $20 \mathrm{~kg} / \mathrm{mm}^{2}$ are $1.9 \% \mathrm{Mo}-5.7 \% \mathrm{~W}-$ $0.67 \% \mathrm{~N}-0.05 \% \mathrm{~B}$ steel, $2.1 \% \mathrm{Ml}--5.2 \% \mathrm{~W}-0.50 \% \mathrm{~N}-0.05 \% \mathrm{~B}$ steel and $1.6 \% \mathrm{Mo}-2.2 \% \mathrm{~W}-0.31 \% \mathrm{~N}$ steel, whose rupture strengths are $26.5,24.1$ and $23.0 \mathrm{~kg} / \mathrm{mm}^{2}$, respectively.

\section{Summary and Conclusion}

In the article above, the basic conditions were determined for safely and surely melting high-Cr steels with a remarkably high nitrogen concentration by employing a new melting and casting method under high-pressure nitrogen. Almost all kind of steel, manufactured by application of this method of melting, shows a good ability for furging, machining, and welding, even when it contains high concentration of nitrogen.

And high strengh heat-resisting steels were developed which contains such elements as $N, M o, W, V$, and B with $25 \% \mathrm{Cr}-28 \% \mathrm{Ni}$ as the base composition. Particularly, to utilize remarkable strengthening effect of high concentration of nitrogen, some of the steels tested vvere prepared using the aforementioned melting method. It was presumed from metallographic and $X$-ray studies that, in the high nitrogen materials with Mo, about $0.2 \%$ nitrogen is retained as dissolved in austenite matrix for long period of testing even at such high temperature as $700^{\circ} \mathrm{C}$, and contributes together with Mo to creep-rupture strength through the so-called solution strengthening mechanism.
Acknowledgmenls

The authors are grateful to Dr. M. Kikuchi for his valuable discussions and for his assistance concerning metallographic research. We are also grateful to $\mathrm{Mr}$. Sawairi for his assistance in performing investigation on weldability.

\section{$\underline{\text { References }}$}

[1] H.H. Uhlig: Trans. Amer. Electrochem. Soc., 87 (1945), 193

[2] W. Tofaute, H. Schottky: Arch. Eisenhüttenw., $14(1940), 71$

[3] V.F. Zackay, J.F. Carison, P.L. Jackson: Trans. ASM, 48 (1956), 509

[4] M. Okamoto, R. Tanaka, et alii: Tetsu-to-Hagané (J. Iron Steel Inst., Japan) 45 (1959), 423, 517, 604,$1351 ; 46$ (1960), 157

[5] A. Sieverts, G. Zapfe: Z. phys. Chem., A-172 (1935), 314

[6] M. Okamoto, R. Tanaka, et alii: Bulletin of the Tokyo Inst. Tech., No. 44 (1961), 1

[7] M. Okamoto, R. Tanaka, et alii: Tetsu-to-Hagané (J. Iron Steel Inst., Japan), 48 (1962), 123

[8] E.R. Morgan, D.N. Frey: Vaccum Metallurgy [Electrochem. Soc., Inc.] (1955), 61

[9] V.F. Zackay, E.R. Morgan, J.C. Shyne: J. Metals, $\underline{8}$ (1956), 216

[10] E.T. Turkdogan, S. Ignatowicz: J.ISI, 188 (1958), 242

[11] J.C. Humbert, J.F. Elliott: TMS-AIME, 218 (1960), 1076

[12] P.D. Pehlke, J.F. Elliott: ibid, 218 (1960), 1088

[13] Y. Kasamatsu, S. Matoba: Tetsu to Hagané (J. Iron Steel Inst., Japan), 45 (1959), 100

[14] K.T. Klochklin, P.V. Gel'd, V.I. Yavoiskii: Dok. Akad. Nauk, SSSR, 84 (1952), 329

[15] M. Okamoto, R. Tanaka and R. Fujimoto: Report, 123rd. Comm. Heat-Resisting Metals and Alloys, JSPS, $\underline{3}$ (1962), 1

[16] O.D. Sherby and P.M. Burke: Prog. in Matcials Science, 13 (1967), 325

[17] R. Tanaka, T. Shinoda and Y. Tobe: Tetsu-to-Hagané (J. Iron Steel Inst., Japan), 56 (1970), 1014

[18] R. Tanaka and $Y$. Tobe: J. Japan Soc. Materials Science (in Japanese), 20 (1971), 354

[19] H.J. Goldschmidt: Metallurgia, $\underline{56}$ (1957), 17 